\title{
The American Occupation of Japan: A Retrospective View
}

\author{
Grant K. Goodman
}

Compiler

International Studies, East Asian Series

Research Publication, Number Two

Center for East Asian Studies

The University of Kansas 


\section{The American Occupation of Japan: A Retrospective View}

Grant K. Goodman

Compiler

International Studies, East Asian Series

Research Publication, Number Two

Center for East Asian Studies

The University of Kansas 


\section{Copyright (C) 1968}

\section{Center for East Asian Studies}

The University of Kansas

Library of Congress catalog card number: $68-65352$

All rights reserved

Manufactured in the United States of America

Sole distributors in the USA \& Canada

PARAGON BOOK GALLERY, LTD.

14 EAST 38th STREET

New York, N.Y. 10016 


\section{Contents}

Introduction ..................... Grant K. Goodman

The American Occupation of Japan: Political Retrospect ..... 1 Robert E. Ward

The American Occupation of Japan: Economic Retrospect .... 11 Martin Bronfenbrenner

The American Occupation of Japan: Social Retrospect . . . . . 27 Edward Norbeck

Comment ........................... 35

John M. Maki

Comment .......................... 39

Harry Emerson Wildes 


\title{
Introduction
}

\author{
Grant K. Goodman
}

The American Occupation of Japan: SCAP, GHQ, ATIS, CIS, CIC; the 8th Army, the 1st Cavalry, the 101st Airborne, the 5th Air Force, the 7th Fleet; the Dai Ichi Building, the NYK Building, the Kaijo Building, the Meiji Building, the Imperial Hotel; Shidehara, Yoshida, Katayama, Hatoyama, Nosaka; Japan's American Interlude, MacArthur's Japan, Failure in Japan, Typhoon in Tokyo, Popcorn on the Ginza. The nostalgia inherent in such evocations need not be belabored here. But the Occupation is over, and the thrill is gone. We who "lived" the Occupation are greying (whether "romansu guray" or not is perhaps not for us to judge), and our girths have gone beyond the limits once imposed by olive drab or khaki. For those of us who, in the classroom, are instructing young people in the several aspects of modern Japanese development, when the Occupation began, this was, horrifyingly, a generation as yet unborn! And we who have had in the intervening years since the Occupation an opportunity to return to Japan have been seeing a Japan now totally unrecognizable from the one we knew in the Occupation era. And yet all of us-Americans and Japanese alike-know full well that the effects of the Occupation continue to be felt in Japan sixteen years since the official end of the American presence.

Thus it seemed to me as a former occupationaire turned academic that before too many of us were too far removed from our own. immersion in the mainstream of the Occupation, it might be well not to attempt to recreate those good old days not quite beyond recall but to try to reevaluate the whole experience. And by so doing, it further seemed to me that we might with the wisdom of hindsight and the acumen of our several scholarly trainings and maturations now make the kind of insightful and informed judgments which were clearly not possible five, ten or fifteen years ago. To this end the papers and commentaries compiled in this volume were presented at the 1968 meeting of the Association for Asian Studies as a panel entitled "The American Occupation of Japan: A Retrospective View."

What seems particularly impressive in the thoughtful presentations of the participants in this symposium is the recognition that the occupation itself, despite its clearcut victor-vanquished relationship, 
was, as a matter of fact a surprisingly mutual undertaking. For as we look back now on the operations of the Occupation and as we assess its triumphs and tragedies, it is obvious that in both instances we are examining actions and reactions, American and Japanese. And what is so intriguing in this interplay is the apparently felicitous mutuality of American catharsis and Japanese trauma. Surely such a result must be unique in the annals of post bellum military occupations anywhere, and it must tell us something about the cultures, the societies and, in particular, the commitments of both Americans and Japanese.

I wonder what this concomitance of the "American dream" with the "Japanese nightmare" can teach both peoples about the nature of their respective histories. For instance, can the Occupation of Japan be viewed for Americans as a sort of culmination of the era of the New Deal? Does the euphoric purposefulness of the Occupation headquarters staff, MacArthur included, reflect the American envisioning of a whole destitute and prostrate society-Japan-serving as a practicum for the world's most advanced techniques of socio-economico-political surgery? Was the determined American effort to restructure Japan from top to bottom a subconscious or conscious attempt to realize at long last and in full measure the ethnocentric American sense of mission? And does the thoroughness with which the Occupation approached its tasks mark a watershed in what continues into our own time to be a primary internationally assumed responsibility of the United States, namely the reshaping of not only Asia but some two-thirds of the world in our own image or as nearly like our image as the world's less fortunate citizens can manage? And further, to what extent has the seeming responsiveness of the Japanese to American "forceful benevolence" (to borrow John Fairbank's term) encouraged Americans to believe in their own special destiny as applicable in other areas of the globe?

For the Japanese, how much was their ability to ingest to a significant extent the Occupation reforms a continuum of the venerable Japanese tradition of cultural borrowing and assimilation? How much was the historical experience of mass acceptance of elitist values in Japan responsible for the "situational ethics" (Reischauer's concept) wherein a whole society could make the effort to adapt itself to the wide spectrum of changes ordered by alien occupiers? How meaningfully could the desires of the Occupation be accepted 
within the broader framework of Japan's nearly eighty years of intensive Westernization? How "open" to change had Japan, in fact, become in 1945 as a result of total defeat and national degradation? And to what extent does the remarkable resurgence of Japan since the end of the war and more so since the end of the Occupation reflect the ethos of the Japanese tradition rather than the impetus of the directives of SCAP?

While this panel represented the most thoughtful kind of American scholarship about these and similar questions, it perhaps behooves me to note here that reassessments of the Occupation are also going on in Japan. For those Japanese "interi" who, like Okuma Nobuyuki, have come to regard the century from Perry's arrival to the end of the Occupation as Japan's "100 Years War" or 100 years of struggle against American imperialism, the Occupation has been interpreted as a "national humiliation," and Occupation personnel have been described as a band of tricksters who entrapped a whole generation of Japanese. Okuma, for example, has argued that the Americans were "deceitful" in making the Japanese believe that a military occupation could produce democracy and has condemned the Occupation for its purging of right wing and ultranationalist elements as in itself an undemocratic act. At the opposite extreme is someone like Yamada Munemitsu who in his bestselling Kiken na Shisoka (Dangerous Thinkers) indicts a large number of leading contemporary Japanese writers, critics and professors as "negators of postwar democracy." Yamada bewails the disappearance of the iconoclasm which he believes to have characterized Japan's intellectual climate during the Occupation period and sees what he defines as the post-Occupation aesthetic relapse as endangering Japan's chance for real democracy. Thus, for thoughtful and articulate Japanese too the Occupation and its aftermath are currently undergoing critical reexamination.

It is evident in the papers that follow that all of the panelists brought to their assigned tasks a profound awareness of the kinds of problems alluded to above, and thankfully these specialists have been willing to share with their peers and their students the insights of their careful research. For the three main papers we were privileged to have leading specialists in each of the three aspects of the Occupation selected for investigation. Our two discussants, by virtue of their academic distinction and Occupation experience, were also especially well qualified to comment on these papers. 
Professor Robert Ward of the University of Michigan, Professor of Political Science and Director of the Center for Japanese Studies, has consistently demonstrated in his numerous books and articles his unique expertise in the politics of Japan and his particular competence in the postwar period. His most recent writings include The Political Modernization of Japan and Turkey, Japan's Political System and Political Development in Modern Japan. Prof. Martin Bronfenbrenner, Chairman of the Department of Economics at CarnegieMellon University, has also taught at such Japanese institutions of higher learning as Tokyo College of Commerce, Doshisha, Keio and Aoyama Gakuin, and he is the author of such books as Prospects of Japanese Democracy, Long Range Projections of the Japanese Economy, 1962-1975 and Academic Encounter: The American University in Japan and Korea. Prof. Edward Norbeck, Dean of Humanities and Professor of Anthropology at Rice University, has written, among several other works, Takashima, A Japanese Fishing Community and the recent Changing Japan. Prof. John Maki, Vice-Dean of the College of Arts and Sciences and Professor of Political Science at the University of Massachusetts, has to his credit such books as Conflict in the Far East (1894-1960), Court and Constitution in Japan and Government and Politics in Japan. Dr. Harry Emerson Wildes has been a scholar of things Japanese for over 40 years beginning with his Social Currents in Japan and continuing through Japan in Crisis and 4liens in the East to his most stimulating work Typhoon in Tokyo ubtitled The Occupation and Its Aftermath. 


\title{
The American Occupation of Japan: Political Retrospect
}

\author{
Robert E. Ward
}

While it might be tempting-writing in the year of the Meiji Centenary-to seek parallels between the historical significance of the events following 1868 and those following 1945, such an attempt would do gross injustice to the facts involved. The consequences of the Restoration-if not the event itself-were truly revolutionary when compared to the circumstances of Tokugawa Japan, while the longterm consequences of the American Occupation, although of major and durable importance, are perhaps better compared to those of an event such as the New Deal period of our own history. The years 1945-1952 were indubitably a time of new beginnings in Japan, but in most cases large and essential portions of the foundations for these new beginnings had already been laid by the Japanese themselves and the discontinuities in institutions, attitudes, and behavior patterns that were involved are not nearly so profound as was the case during the early Meiji Period.

In any attempt to look back at and evaluate the political aspects of the American (technically, the Allied) Occupation of Japan, it is important to keep this type of historical perspective in mind. In an historiographical sense it so often seems that the closer a scholar is in point of time to the event that he is analyzing, the more he tends to emphasize idiosyncratic and contemporary aspects of the causes involved. This is the epistemological basis for revisionism in the writing of history. Where the American Occupation of Japan is concerned, a realization of this fact constitutes a warning against exaggerating the role of the Occupation itself as the sole or major cause of postwar political developments in Japan and, reciprocally, against undervaluing the role of more endogenous causes. With this much introduction, permit me now to turn to a more substantive examination of the political aspects of the Occupation.

May I remind you first of a few of the basic facts about the American Occupation of Japan. It lasted for six years and eight months, from September 2, 1945 to April 28, 1952. For all but 
thirteen months of that period General Douglas MacArthur served as Supreme Commander for the Allied Powers (SCAP). It was throughout a military occupation. In a legal sense American authority over Japan was for all practical purposes complete and unchallengeable. Japan was isolated from normal contacts with the outside world for most of the period concerned. Her citizens could not travel abroad nor could foreigners visit Japan without specific approval from SCAP. Both her external and internal communications were monitored and subject to censorship.

Most important of all, the American authorities approached their postwar task in Japan with attitudes and goals that were in part political and in part evangelical. The prime official objective of the Occupation to begin with was the disarmament of Japan and the establishment of conditions calculated to prevent any revival of an aggressive Japanese threat in the Western Pacific. As a somewhat ethnocentric aspect of this endeavor it was felt that the democratization of Japan would provide the best possible longrange guarantee for this peaceful and responsible conduct in the future. In confronting this daunting assignment the Washington planners and the Occupation authorities soon perceived that any meaningful program of democratization involved far more than a purge and a bit of tinkering with the specifically political institutions of state. Fairly systematic attempts were made to introduce into Japanese politics, and subsequently to cultivate and protect, such basic democratic institutions and principles as popular sovereignty, limited and responsible government, broad civil and political rights, universal adult suffrage, legisłative supremacy, a competitive party system, judicial independence, executive and fiscal accountability, and decentralization and local autonomy. But in addition to such specifically political initiatives attempts on a quite impressive scale were also made to provide an appropriate social and psychological infrastructure for a democratic political system. This was one of the goals, for example, of the programs of educational reform, improvement in the general status and rights of women, changes in the family system and family law, encouraging the organization and activities of labor unions, land reform, and reform of the media of mass communications. Later on, of course, there were changes in the original objectives of the Occupation. In 1948, for example, economic rehabilitation was added to demilitarization and democratization as a third major goal, while in 
1950 we abandoned demilitarization as a goal and began to encourage Japan's rearmament. At no point, however, did we abandon democratization as a major objective, although, for several reasons, it did become a somewhat less salient aspect of the Occupation's activities from late 1947 or early 1948.

Any retrospecive judgment of the success or failure of the political aspects of the American Occupation must be geared to this structure of goals. In applying them, however, it is useful to emphasize several general points at the outset. The first is that ideal standards of democratic performance have no more been attained in Japan than in the major Western democracies. It is necessary, therefore, to temper idealism with a healthy measure of realism in essaying judgments on this score. Second, in doing this the single most relevant benchmark is the level of pre-1945 democratic performance in Japan in relation to post-1945 changes therein. In this respect at least two more specific temporal frames of reference are helpful. The most proximate and obvious is, of course, the years immediately preceding surrender, the period of ultranationalism and authoritarianism that is usually dated from 1932 to 1945 . While valid and meaningful for many purposes, I would suggest that in some respects it is also helpful to consider standards of democratic performance in Japan during the years immediately preceding this as well, the period that the Japanese call kensei no jodo or the time of normal constitutional politics form 1924 to 1932 . Finally, it should be appreciated that a judgment of this sort relates to past and present democratic performance during the postwar period not to prospects for the future. No one canguarantee the stability of democracy in Japan, or for that matter, elsewhere.

Given these caveats, I should say that the most important general observation to be made about the political reforms launched by the Occupation is that they have proved reasonably successful. Permit me to supply a few particulars in support of this claim.

In a specifically political sense, the doctrine of popular sovereignty has been solidly established in Japanese public law and in judicial practice. Even strong advocates of constitutional revision, with a few exceptions of currently negligible importance, do not call for change in this respect. Judged by the standards of contemporary practice in other democracies, Japan obviously has a limited and responsible form of government. The executive is sensitive to the 
views of both its supporters and its opponents in the legislature and, in measure, responsive thereto. Both the executive and the legislative branches of the government regularly submit their records and programs to the judgment of the electorate. This electorate has expanded enormously since the war and now includes substantially all adults of twenty or more years of age. Japanese citizens as a whole are constitutionally guaranteed an array of civil and political rights that is matched in very few modern states. The judiciary is independent, professional, and comparatively speaking, quite effective. Public funds are raised and expended only as a result of legislative action and are routinely subject to accounting practices and safeguards. A competitive party system has been established and, despite occasional and ominous stalemates, has so far managed to function at an acceptable level of efficacy. And there has been an appreciable degree of decentralization of political, administrative, and fiscal authority to prefectures, cities, towns, and villages.

If one looks to the political process rather than to political institutions, the results are not dissimilar. The role of elections is basic to the power structure. Public opinion has acquired a new role and force. The structures of the society and of the decision-making system have become far more open and pluralistic. Interest groups have multiplied rapidly and so has their influence on policy. The opposition parties, although unable to achieve power and office in the formal sense, have acquired an effective veto over government action in certain important spheres. And the decision-making process as a whole has become more open, more accessible to non-official scrutiny and influence, and ultimately, more accountable and responsible than ever before in Japanese history.

In a somewhat different category it is, of course, possible to consider both demilitarization and remilitarization as political goals of the Occupation at different points in time. In this event I suppose one would have to say that the Occupation was more successful in achieving the former-demilitarization-than the latter-rearmament after 1950.

Where the social and psychological infrastructure of a democratic political system is concerned, there have been equally notable innovations. The school system has undergone enormous changes. Whereas in 1940 only forty-six per cent of children in the age group attended secondary schools, the present figure is over eighty per cent. For 
higher education the comparable figures have quadrupled from 3.7 per cent in 1940 to upwards of fifteen per cent today. The content and emphasis of education have also changed a great deal. Similarly the status of women, and indeed of the family system as a whole, has been drastically altered in post-war Japan. Of equally basic importance are the alterations that have occurred in the quality of rural life due to improved communications, the diversification of economic opportunities, changes in agricultural technology, and extensive migration to the cities on the part of farm youth. The agrarian revolution is at last coming to Japan and, as it progresses, one of the main pillars of traditional politics begins to topple. The growth and importance of labor unions has had a somewhat similar unsettling effect upon traditional relationships and attitudes among the urban population. While no one of these developments leads inevitably to democratic political consequences, all of them combine to destroy the underpinnings of traditional society and the system of politics that was associated with this in Japan, and in this sense create a most important potential for change. Given the prevailing institutions and commitments of the society, the bulk of the organized effort is directed toward insuring that these changes will be democratic in nature.

Obviously none of the foregoing institutions or developments has completely fulfilled its democratic potential or, for that matter, the aspirations of those in SCAP who initially launched the reforms concerned. But while freely acknowledging all the flaws, shortcomings, and retrogressions that have taken place from the standpoint of puredemocratic theory, I still find the following aspects of Japan's postwar political performance impressive.

First, there has been no massive or basic replacement of the democratic innovations introduced by the Occupation. It is not difficult to identify instances of piecemeal change or of administrative subversion of institutions or plans cherished by the Occupation-some of them of appreciable importance. But sixteen years after the end of the Occupation the essential political structure remains intact and operative. We tend to forget just how remarkable a phenomenon that is. Certainly few foreign students of Japan anticipated such an outcome at the time. Most of us-myself included-were too preoccupied with pointing out the yawning gap that seemed to separate the Japanese political heritage and style from these new American in- 
spired and imposed institutions and with predicting their imminent demise or drastic transformation once the Japanese regained control of their own affairs.

Second, the attempts that have been made since 1952 to revise the political structure installed during the Occupation have been more notable for their moderation than for any endeavor to revert to the institutions and practices of prewar Japan. The most full-dress example of such an attempt is to be found, of course, in the proceedings of the Kempo Chosakai or Commission on the Constitution that functioned between 1957 and 1964. As one reviews both their objections to the constitution of 1946 and their proposals for changes therein, it is difficult to avoid the conclusion that the consideration that affected most of them most deeply was an entirely understandable sense of the fundamental indignity of having a constitution that was originally written by foreigners in a foreign language and then imposed upon them by means that at the very least raised substantial doubt about the meaningfulness of Japanese participation in the decisions involved. With very few exceptions, however, their substantive suggestions for change have been in no way startling and in no serious way calculated to alter or subvert the democratic foundations of the political system.

Third, this is the more surprising and impressive when one considers how great are the differences in basic power structure and in political process that distinguish postwar from prewar Japan. While I do not subscribe to the thesis that Japan in the thirties and early forties was a Fascist state, it most certainly was an extremely authoritarian one. Furthermore, this particular governmental form was the product of what is undoubtedly a dominant authoritarian theme that characterizes the entire known history of Japanese political culture. It is specifically with reference to this long history of authoritarian political institutions and practices that the political developments in postwar Japan are most impressive. Indeed, if the historical perspective were restricted to only the post- 1932 period, it would seem that one was confronted with a truly remarkable instance of cultural discontinuity. Herein, however, lies the value of the 1924-32 period as an historical referent. It makes manifest the minor themes, democratic in tendency, that persist and interact with the dominant authoritarian theme to provide important elements of support and continuity for the democratic innovations of the Occupation period. 
Even by the more liberal standards of kensei no jodo, however, the political developments in postwar Japan mark a most impressive break with the past.

Finally, I am impressed also by the sheer passage of time and the implications that this has for the continued viability of democratic politics in Japan. Sixteen years have passed now since Japan regained her sovereignty in April, 1952. Given time, some cultural preparation, and a level of practical performance that falls short of the disastrous, most people tend to adapt to almost any political circumstances. It is far easier to do so when, as in the case of Japan, the political performance of postwar governments has been more than adequate and the economic performance spectacular. Under such circumstances the political system tends to acquire a quality of inertia that adds markedly to its capacity for survival. I take this to be the case in Japan.

It is for reasons such as these that I consider the American Occupation to have been on balance a remarkably successful experiment in directed or planned political change. I should not, however, like to leave the impression that in an historical sense these changes are to be attributed solely to the presence and influence of the Occupation authorities. The patterns of causality involved are extraordinarily complex. My own view of what happened in this respect goes essentially as follows.

In a psychological and cultural sense Japan was as totally unprepared for defeat and occupation as any major society in history, with the possible exception of the United States. The attendant shock was the greater, therefore, and its effect was extended and reinforced by the desperate economic and physical straits of the populace in general during the early postwar years. The most important political consequence of these circumstances was an intially rather unfocussed sense of disillusionment with the political leadership and institutions that had brought the country to such a sad pass. Scapegoats were a political and psychological necessity and in practice the militarists and ultranationalists were cast for this role with minor parts reserved for a some what motley assortment of former conservative politicians, ideologues, and professional bureaucrats. This sense of disillusionment and blame attached also to the political system with which these individuals had been associated, particularly to the institutions and practices that had developed since 1932. The general conse- 
quence of this combination of circumstances was to produce a sort of massive but initially unfocussed potentiality for political change in postwar Japan. The society and many of its institutions were, for the time being, in a far more than ordinary condition of plasticity or malleability. This is the passive or pre-disposing side of the pattern of causality involved.

Two further groups of factors of major importance must be added to this. The first is the pressure of a technically all-powerful Allied Occupation committed to a program of democratization and equipped with a growing arsenal of plans to this end and designs for acheiving these plans. The second is the persistence throughout postRestoration Japanese history of a relatively liberal and democratic element in the society's political culture. Japan's is not a monolithic political culture in which only the institutions and practices of authoritarianism prevailed. In modern times there has always been a relatively liberal element as well, normally associated with the political parties.

One hesitates to say that one of these factors-the Occupation, for example-was basically more important than the other-the liberal tradition in Japan. The Occupation undoubtedly catalyzed the entire process and was responsible for the imposition of particular formats and timings on the entire process of political change in postwar Japan. There is little that suggests that the Japanese, if left to their own devices, would have produced substantially equivalent results. Also the Occupation was in a position to eliminate or quell the forces of domestic opposition to changes of a democratic character and thus, so to speak, to hold the field for the more democratic elements in Japanese society until they were better able to go it alone.

But, on the other hand, without substantial and durable support on the Japanese side the whole edifice of change would have collapsed with the withdrawal of the American forces. That it has not done so is testimony to the vitality of the relatively liberal strain in Japan's political tradition and to the capacity of the exponents of this liberal strain to expand their support and strength under the favorable conditions of plasticity and new opportunities that existed in postwar Japan. Of great importance also were the operational skills that the Japanese had acquired since 1890 in the conduct of elections, party affairs, parliamentary government, etc. These skills 
were quite readily convertible to the management of the more democratic apparatus of state in postwar Japan.

If one looks at postwar Japanese politics in this light, the discontinuities become less profound and the role of the Occupation is reduced from that of deus ex machina to that of essential catalyst and form-giver. Under such circumstances it is obvious that whatever the degree of success that may be attributed to these postwar political changes in Japan, the credit is certainly to be shared between the domestic and the foreign forces involved. 


\title{
The American Occupation of Japan: Economic Retrospect
}

\author{
Martin Bronfenbrenner
}

God loves Americans, and the Oriental gods love Japanese, else the Occupation of Japan could never have succeeded-Harry Emerson Wildes

\section{Occupation, Reconstruction, and Development}

The 99 44/100 per cent American occupation of Japan became, within a few months of the end of World War II, a venture in economic reconstruction. Like other large-scale reconstruction ventures, it was closely allied to a venture in economic development. Therein lies much of its general interest and importance.

The Occupation involved a reversal of the development check imposed by domestic war damage, plus the loss of monopoly privileges in the import markets for finished goods and the export markets for raw materials and labor of countries which had been Japan's overseas Empire. These losses were severe. I shall not burden you with statistical guesstimates, but the war damage alone, exclusive of neglected depreciation, has been estimated at one-fourth of Japan's pre-war national non-human wealth, including land but excluding "human capital."1 However, labor skills, land, and social overhead capital had survived with relatively minor damage.

Economists should also note that Japanese self-confidence, along the lines of "we did it before, we can do it again," revived within perhaps two or two and a half years after the first shock of defeat had passed, and after it became clear that no wholesale destructionor dismantling of Japanese industry was in the cards. I think we can agree that shortages of labor skills, social overhead, and what social psychologists call "achievement motivation" are more important in holding back genuinely under-developed countries than is yet recognized in either formal-economic models or empirical-economic input-output tables. To the extent that Japan retained them all, or recovered them by, say, 1948, the Occupation's reconstruction problem was less acute than a genuine development problem of the same magnitude would have been.

\section{Biases of the Writer}

As an ex-Occupationnaire, I find it difficult to control my prejudices when considering any aspect of the Occupation. Fortunately, 
my two biases pull me in opposite directions. On the one hand, the Occupation gave me (at the expense of poverty-stricken Japanese) a higher standard of living than I ever enjoyed before, and possibly since. But then, after a year of this unearned increment, the Occupation nearly expelled me from Japan, branded as a subversive or proCommunist. And so, you see, I can be more or less "objective" about it.

On balance, my position is that the anti-Occupation reaction, since General MacArthur's ouster in 1951 and the resumption of complete Japanese sovereignty a year later, has been extreme and unfair to MacArthur's accomplishments. This is particularly true in Japan, where the Korean War tends to receive all the credit for sparking Japan's recovery without reference to the years preceding.

\section{Handicaps of the Occupation}

A principal reason for harshness in judging the Occupation has been bedazzlement with its ostensibly unlimited power to "roll up its sleeves and make Japan over," and forgetfulness of the handicaps under the dictatorial surface. I should like, therefore, to consider a half dozen of these handicaps, which are frequently overlooked, and which often apply to similar operations elsewhere.

1. Perhaps the most important handicap of the Occupation was its impermanence, which was anticipated from the outset. (It lasted less than seven years, until 1952; original hopes were for only three or four years.) Impermanence led, on the Japanese side, to passive resistance and waiting the Occupation out. It led, on the American side, to excessive zeal and haste, ramming reforms down Japanese throats in a race against time, without regard for Japanese opinion.

2. Second only to impermanence were the personnel inadequacies under which the Occupation suffered at all levels. The civilian working staff included too few people for the job assigned them, and those few were overly concentrated in Tokyo. The great majority undertook their jobs with little or no background in Japanese language, history, culture or institutions. They were, furthermore, under the control of military men less prepared than themselves for the responsibilities of civil government. For example, the major interest of the general supervising the entire Economic and Scientific Section of MacArthur's headquarters (called SCAP, or the Supreme Commander for the Allied Powers) was the revival of professional baseball in Japan. One of the historical sections was governed for a time by a 
military efficiency expert who regulated the output of history at so many paragraphs per historian per day. ${ }^{2}$ Some of the top-ranking civilians, too, being ex-soldiers as well as economists or sociologists, saw their functions as anticipating and rationalizing every twist and turn in the thinking of their military superiors, and they often acted as advocates or yes-men rather than as intellects or consciences.

A final personnel problem was the rapidity of turnover, possibly leading to a downward trend in quality. ${ }^{3}$ Military rotation, opportunities in the United States, and private business in Japan continually skimmed the cream of the SCAP civilian and military economists away from their Occupation jobs. (Certain of these jobs had been assumed at the outset on a leave-of-absence basis from some Washington bureau or university campus.) Special "Missions" supplementing the efforts of the regular staff, were usually one- or two-shot affairs, lasting a month or two at a time. Mission members sometimes had even less Japanese background than the Occupationaires and (in most cases) little or no liaison with them. In addition, the staff tended toward jealousy of the Mission's prestige and glamour and to resentment of the derogation implied in the Mission's being sent for in the first place. They were occasionally incapable of understanding, let alone supplementing, technical details of the sketchy Mission recommendations whose broad outlines they were expected to implement. As if this were not enough, rivalry and intrigue within MacArthur's inner circle resulted in periodic "purges" of the losing general's or colonel's subordinates. These purges are best described as McCarthyism before McCarthy. I have no idea how many professional careers they affected, either temporarily or permanently, or how many people they transformed, temporarily or permanently, from men into mice.

3. For all its power as seen by the Japanese, the Occupation was subject to every change of American policy toward East Asia. These changes in turn affected what the Occupation was trying to do in Japan and to its Japanese wards. A major policy watershed, of course, was the decline and fall of the Kuomintang on the mainland of China in 1948-1949. Prior to 1948, high policy had been to build up China at Japan's expense. This meant, for Japan, holding down heavy industry to the amount required for her 1934-36 living standard, and the dismantling of a constantly re-estimated number of plants which had produced war materials. (Some of these were to be 
shipped to various Allied countries, primarily China, as reparations.) It also meant a punitive policy toward traditionalist Japanese and toleration if not support for the Japanese Left. In and after 1948, policy changed to the restoration of Japan's pre-war position as the "workshop of Asia" and to the preservation of her economy as far as possible from Socialist encroachments.

4. The Occupation was harassed constantly by suspicion from business circles in the United States itself. To some extent, this came from firms and industries fearful of Japanese competition at home and in world markets. Primarily, however, the suspicion of American business was focused upon left-wing New Dealers in the SCAP organization, with previous experience in such "anti-business" agencies as the Office of Price Administration and the Anti-Trust Division of the Department of Justice. Briefly, American business feared the development in Japan of blueprints for direct and indirect control of business, which could be applied in America at some future date.

5. We have spoken already of Japanese attempts to wait the Occupation out. The motivation for these attempts was, naturally enough, suspicion of specific Occupation policies by conservative Japanese. This suspicion was focused along two lines and formed a dilemma to which the Occupation never found an appropriate answer. If Occupation policy involved "reform" along the lines of American practice, the Japanese answer was "Japan is not America." If, on the other hand, an Occupation policy differed from American practice, and particularly if it was of innovative character, the Japanese criticism was: "Too theoretical-Japanese are not guinea pigs!"

6. The final handicap of the Occupation was the weakness of co-ordination, or what we call today the "systems approach," as between its several sections and bureaus. These often operated at cross purposes, each striving for some particular bits of recovery or reform regardless of cost or other implications to the economy as a whole. One focus of conflict was the national budget, where Occupation offices lined up to seek tax exemptions, subsidies, and expenditures for their favored sectors, projects, and for special groups of "their" Japanese. The sum total of all these privileges, despite the best efforts of the Finance and Public Finance Divisions, came to more than Japan could afford, especially after inclusion of extravagant "termination of war" expenses to support the Occupation itself. 
The remainder of this paper will consider three substantially successful Occupation programs in the economic sphere, and then three partial or complete failures. My thesis is that the successes did not require the co-operation of many Japanese, other than their immediate beneficiaries, and therefore lay within the Occupation's power. When we come to the failures, I shall argue, more general Japanese co-operation would have been required, but was not achieved.

The three successes I have in mind-and they are not the only ones I might have chosen-are the relief and rehabilitation program, the agricultural land reform, and the control of American "carpetbaggers."

1. In point of time, relief and rehabilitation was the first program to get under way, despite the Occupation's initial disclaimer of responsibility in these fields. ${ }^{4}$ It was also one of the longest lasting, continuing after Japan recovered her independence and the Occupation shut up shop. It was a highly expensive program, amounting to $\$ 2.118$ billion in aid alone over the period from September 1945 to December 1951. This estimate ignores entirely $\$ 1.565$ billion of "procurement" in 1950-52 connected with the Korean War, some proportion of which might have been reclassified as aid. ${ }^{5}$

The accomplishments of this $\$ 2$ billion-plus program are well known on the political side, more dubious on the economic one. It clearly reduced epidemic disease, starvation, and civil disturbance in the early postwar years, although it could not eliminate them completely. (Cynics suggest that its main motive may have been to keep Japan safe for the Occupation itself.) The program also assisted in the repatriation of six million Japanese refugees or repatriates. These included, in addition to war prisoners, civilians who had settled in China, Manchuria, and the former Overseas Empire (Korea, Taiwan, and the South Seas). At the same time, the program thwarted Communist hopes for a fifth column of former Siberian war prisoners, for food riots, or for general strikes. The program also began, on its industrial front, the reconstruction and modernization of Japanese manufacturing, and included technical assistance on a scale larger than President Truman's later Point Four provided for any developing country. In Japan itself, there is a tendency to downgrade this aid and date the beginning of real recovery from the Korean War of 1950-52. This feeling was not shared, while the Occupation's pro- 
gram was under way, by other Asian countries. Korea, Taiwan, and the Philippines, and also China before 1948, were all extremely jealous particularly of the industrial aspect of American assistance to Japan, in which they never shared to any proportionate degree.

2. The special circumstances of the Occupation permitted SCAP to ride roughshod over agricultural landlords' interests, and redistribute some 38 per cent of Japan's agricultural land from landlords to tenants on terms largely confiscatory to the former. ${ }^{6}$ To call this land reform a success is not to credit it with positive contribution to the country's recovery, but rather to point out its political implications. Combined with parity prices for the farmer's major crops (after an American model generally regretted by economists in its country of origin) Japanese land reform raised peasant living standards, both absolutely and relatively to city dwellers. This in turn has created in the countryside a mass political base for anti-Socialist parties and against any proposal for agricultural collectivism. In retrospect, this political effect seems to have been the principal purpose of the reform all along, not only in Japan, but in other Asian countries where land reform "American-style" has been attempted.

Unlike some other experiments in land reform, the Japanese one was carried on without reducing Japanese agricultural productivity. As a matter of fact, the steady postwar increase in agricultural productivity is the main factor holding Japan's staple food import percentage to approximately its prewar level or 15 per cent despite a 30 per cent rise in population! It is still a matter of dispute (largely ideological) whether agricultural productivity might not have- increased even more under a collectivist program. The Marxist majority of Japanese agricultural economists are sure that it would have done so. The "modern economic" minority are equally sure that it would not. Not being either an ideologue or an agricultural economist, I must confess myself unable to take a stand on this important issue.

3. The last economic success of the Occupation that I want to mention is the anti-carpetbagger program. A carpetbagger, as we remember from the history of the period immediately following the American Civil War, comes to an occupied area with an occupying army (of which he may be a member). He then takes advantage of his special status in that area to acquire property or business connections "on the cheap," if not by force or fraud.

MacArthur's Japan was full of rumors of carpetbagging. They 
circulated both among Japanese and Americans. I was myself assured time after time, chiefly by left-wing Japanese professors and students, that this or that factory, dockyard, department store, or choice block of downtown real estate was already owned by some American or some American company. In due time, I was told, American ownership would be revealed.

SCAP as an organization, although not all members of its civilian and military staff, tried as a policy matter to eliminate this carpetbagging. Apart from criminal prosecution in flagrant cases involving theft, bribery, or black-marketing, its main weapon was exchange control, under which the proceeds of the eventual sale of Japanese property could not legally be withdrawn from Japan.

Post-Occupation results seem to have belied the rumors which I heard. No significant fraction of Japanese landed property or capital wealth seems to have found its way into American hands. Carpetbagging seems to have been confined to personal or consumers' capital (kimonos, books, objets d'art) which Occupationaires and others could take home with them. The question remains, how much of this record is really due to Occupation policy, and how much to forecasting errors by individual Americans about Japan's economic future. Japanese real estate, to cite one example, remained extremely cheap (but not recognized as any great bargain) all through the Occupation and into the mid-fifties. One wonders how much Americans might have bought up, despite Occupation policy, if they had forecast realestate values of the mid-sixties fifteen or twenty years in advance.

\section{Three Occupation Failures}

We turn next to three occupation failures in the economic sphere. My thesis is that they occurred primarily in fields where, for all SCAP's "lack of humility bordering on pretensions to infallibility" and "occasional tendency to rattle sabres and settle an argument by pounding the table and invoking the authority of the Occupation," Japanese interests adversely affected could outsmart the excessively mobile Occupation personnel or wait for the resoration of Japanese independence. In addition, however, positive economic errors in the Occupation's higher echelons played an important part in at least one instance-the Japanese inflation of 1945-1948.

l. Let us, then, consider the Japanese inflation over the four-year interval 1945-49 as the Occupation's first economic failure. (The 
disinflationary reforms of Mr. Joseph Dodge and Professor Carl Shoup took over for approximately a year in 1949. The subsequent resumption of inflation, at a slower pace, is associated with the Korean War.)

The Occupation inflation was a major one, although never attaining the technical dimensions of hyper-inflation, namely, a price rise of at least 50 per cent per month. ${ }^{8}$ With $1934-36$ as 100 , the index of Japanese wholesale prices rose from 350 in 1945 to 20,876 in 1949. A similar series for retail prices in Tokyo rose from 308 to 24,337 in the same period. ${ }^{9}$

It is probable that a considerable inflation would have been brought on by Occupation blundering without regard to Japanese reactions, by reason of the excessive strain the Occupation imposed on the Japanese fiscal system. We have mentioned the lack of anything like a "systems approach" on the part of the Occupation, and also its insistence on getting things done quickly and irrevocably before the Occupation ended, with no regard for real or monetary cost. In addition, Occupation policy saddled the Japanese with "termination of war" expenditures, including the support of the Occupation and its dependents in better-than-American style. Even if the Japanese had been willing to bear the resulting tax burden which would have exceeded the wartime one in real terms, it would have been difficult to grind the necessary revenues and resources out in time. In fact, the Japanese were no more willing to be taxed for Occupation purposes than could be expected under the circumstances of foreign occupation.

No serious attempt was made, by either the Occupation or the Japanese, to control either the volume of currency printed or the volume of bank deposits created to support not only the Government deficit but also similar deficits of private firms. It seems especially strange, in retrospect, that stringent ratios of reserves to deposits were not imposed and enforced on the Japanese banks. However, the late forties was perhaps the most extreme period of the most extreme form of Keynesian doctrine, prior to the so-called "rediscovery of money" at the turn of the decade. According to this doctrine, the quantity of money did not really matter. To cite a Japanese example of such extreme Keynesianism, Tanzan Ishibashi, editor of the Oriental Economist and Finance Minister in the first Yoshida cabinet, maintained that no budgetary deficit or monetary expansion 
could be called inflationary, whatever might be happening to the price level, so long as there remained persistent unemployment. And among the Americans, many ex-OPA economists from Washington brought with them to Tokyo the anti-quantity-theory doctrine that the way to check inflation was price control. Supply at controlled prices could be assured by subsidies, the subsidies could be paid from increased budget deficits, which themselves could be financed by monetary expansion. These OPA hyper-Keynesians also found nonKeynesian allies in Japan, where similar doctrine had prevailed among the military and in the wartime agencies of economic control.

However, the main internal Japanese force for inflation came neither from politician-journalists like Ishibashi nor from bureaucrats in price-control offices, but from big business (Zaibatsu) firms which had had war contracts with the Japanese Government. The Occupation had cancelled the Japanese Government's unpaid debts on these war contracts, but not the contractors' debts to their own suppliers, or their expenses of reconstruction and reconversion to peacetime pursuits. To save themselves, the contractors descended upon the banking system for loans and more loans. The banks granted each successive application (to favored and affiliated companies) to keep their debtors afloat, because they themselves would go under if their major debtors did. In almost the same way, the commercial banks financed their own loans by borrowing from the Bank of Japan. Their questionable paper became the Bank of Japan's major asset, whose value had to be maintained by keeping the banks afloat, whatever happened to the quantity of money or the price level.

Needless to say, there was no reluctance, on the part of either former war contractors or their banking affiliates, to let inflation forgive their debts as the Occupation had forgiven their debtors, primarily the Japanese Government. Indeed, it is more than likely that, without substantial inflation, most of Japan's war contracting companies and the banks which financed them would have failed like Confederate companies and banks after our own Civil War. ${ }^{10}$ If this had been allowed to occur, it would have been the greatest financial collapse of modern Japan.

2. The Occupation's major campaign against the Zaibatsu was a dissolution program whose ultimate failure was as resounding as the postwar inflation itself. It failed both to punish the Zaibatsu companies allegedly involved in and profiting by Japanese militarism ${ }^{\mathbf{1}}$ and 
to rebuild Japanese capitalism much closer to the pure competition or anti-trust act model the Occupation had in view.

The major studies of this Occupation campaign ascribe its disappointing outcome to a paucity of zeal within the Occupation, the artful dodging of individual Zaibatsu executives, and the insidious "influences" exercised by wealthy Japanese over key Occupation personnel. Without denying the existence of any of these lurid factors, I myself conjecture that the difficulty lay deeper in the weakness-one might almost claim, the absence-of Japanese support for the Occupation's program.

Let us explore this matter further. Apart from a few liberal economists, Japanese conservative and pro-capitalist opinion was pro-Zaibatsu as well, looking on bigness as an economic necessity and on big business leaders as only one level below Momotaro and General Nogi in the pantheon of Japanese supermen. Japanese leftists agreed on the necessity for bigness, and wanted it brought under Government or workers' ownership and control. Apart from the aforementioned liberal economists, there was no intermediate group between those satisfied with the economic structure essentially as it had developed before World War II and those satisfied with nothing less than nationalization, confiscation, or seizure by striking workers. The American model, with its anti-trust legislation and its purely-competitive ideals, had inspired no influential Japanese spokesmen. This was hardly surprising, considering its questionable effectiveness even in American economic practice.

The Japanese reaction, on both Right and Left, to the anti- $Z$ aibatsu group of Occupation reform proposals went beyond what one might call the "standard" indifference, with some concern about how much it would cost and which groups of Japanese would pay the bill. The reaction in this case was a bitter one, including unjustified suspicion of Occupation motives. The whole scheme was supposed to be part of some vast conspiracy to drive Japanese industry from international competition by making its firm sizes uneconomically small and its costs uneconomically high. Even when the Zaibat$s u$ 's American competitors joined the hostile chorus, largely from fear of a dose of the same medicine in the United States, this suspicion did not die down. As late as 1955, after the smoke had cleared and the Occupation ended, I was asked by ranking conservative economists at Keio, one of the greatest private universities in Japan but 
with a long history of Zaibatsu connections, whether the "conspiracy" theory was not, after all, historically true.

In this state of public opinion, the Occupation reforms failed almost as completely as though their embodying legislation had failed in the Japanese Diet. They were thwarted chiefly by the Zaibatsu banks, who replaced the family holding companies (dissolved by the Occupation) and held the Zaibatsu firms together by the purse strings. A second sense of failure was the Ministry of Trade and Industry (MITI) which sponsored cartels to cut production and maintain (or raise) proces in a wide variety of circumstances and a wide range of industries.

Professor Yamamura ${ }^{12}$ has summarized the problem in this way: The dominant Japanese preference, certainly on the Right and to some extent on the Left as well, has been for economic growthinitially, for rapid recovery-even at substantial cost in economic democracy. The opposite preferences of the Occupation, and of subsequent foreign critics have been quite irrelevant in the long run. Unsofar as Yamamura (and others) are correct, we have seen another important differential between Occupation economics and development planning. The Occupation cared enough about economic democracy to sacrifice for its sake a certain quantum of economic growth. (It is easier to prescribe sacrifice for foreigners than for oneself.) The Japanese, like any other self-consciously developing country, make occasional loud noises about economic democracy, or such equivalents as "the Socialist pattern of society," but will seldom risk, for either democracy or Socialism, a tenth of a point of measured statistical growth.

3. Our third and last example of an Occupation failure is its trade-union policy. Here its principal Japanese antagonists were primarily to its Left, whereas in the other two cases discussed, they were primarily on the Right of the Japanese political spectrum and to the Right of the representative Occupation economist.

Occupation labor policy included, from its beginning in 1945, the fostering of a large and powerful trade-union movement concerned primarily, like the American AFL and CIO, with economic rather than political activity. In the standard taxonomy of trade-union types, Japanese unionism was to be business unionism, and not political or revolutionary unionism.

Trade unions of any sort had been illegal during Japan's militarist interlude. Under Occupation protection, they grew large and power- 
ful within a year. To this extent, Occupation policy may be said to have succeeded. On the other hand, Japanese unionism has been almost from the outset primarily political, like unionism in continental Europe, rather than primarily economic on the American model. Moreover, its politics have been consistently anti-capitalist, and turned increasingly anti-American in the last years of the Occupation. At the present time, the largest Union federation, Sohyo, built up by the Occupation as a "moderate" counterweight to the "radical" Sodomei, has become the muscle and the pocketbook of the Socialist Party, while a minority faction would prefer affiliation with the Communist Party. To this extent, the program may be listed as an Occupation failure.

It seems strange today that so many Occupation labor strategists of 1945-46 could have expected business unionism to take root, or an Oriental Gompers to flourish, in postwar Japan. Many of these Occupation planners were influenced by the Wisconsin School of labor economists, who had argued that the character of a national labor movement is determined by broad social and economic forces. Thus, according to Professor Selig Perlman, ${ }^{13}$ business unionism was natural on the American scene for three principal and interrelated reasons: (a) American workers were craft-or guild-or industry-conscious rather than class-conscious in the Marxian sense; (b) American capitalism was sufficiently strong to make general strikes and revolutionary campaigns impractical, even without Government intervention; and (c) the influence of intellectuals, particularly radical intellectuals, was weak in American society, including the manual workers. So far so good, but in Japan, the milieu was more European than American. Class-consciousness was stronger than craft- or guildconsciousness; capitalism was weaker in 1945-46 than in almost any prior or subsequent peacetime period since the Meiji Restoration of 1868; the influence of the intellectuals, always strong in Japan, was seldom more so than after the overthrow of their military rivals. Political unionism of an anti-capitalist bent was what one should have expected for Japan on the basis of Wisconsin theory, the supposed party line of American strategists.

Such fatalism, however, was not for the A. F. L. representatives in Japan. From the outset they and their allies strove to turn Occupation labor policy to transplanting "democratic" business unionism on the Gompers model, whose indigenous backing in Japan was limited to a few labor economists who had studied in America. 
For the first year and a half of the Occupation, the A. F. L. influence on its labor policy was relatively weak, and other Occupation labor specialists attempted neutrality as between business and (leftist) political unionism. This was called by the A. F. L. spokesmen "turning Japanese labor over to the Communists;" it often had precisely this effect. Then the left-wing unions planned a general strike for February of 1947. Whatever their grievances-and there were many - this was a tactical error. The plan brought on one of the sudden reversals of the Occupation line on which we have commented as breaking down Japanese confidence in and the general credibility of Occupation policy. The general strike was banned, along with strikes by public employees. SCAP's Labor Division was purged, and the weight of the Occupation was thrown behind the A. F. L. viewpoint-without permanent success. Possibly the failure might have been less egregious had the A. F. L. position dominated from the start, although such an opinion is seldom heard in Japan.

The key point of the failure, in my view, is again the lack of indigenous support-this time, for business unionism. The Right did not want strong business unions. They preferred weak unions, or none at all; union ideology was of secondary concern. The Left wanted political unionism of a revolutionary cast, as the labor arms of Socialist or Communist political parties.

Under these circumstances, what the Occupation created has become a Frankenstein monstrosity, in the form of an anti-capitalist, anti-American union movement of considerable strength. It has become an important but permanent minority in Japan, aiming at a degree of political power for which it has little chance under the existing (parliamentary) rules of the political game. Its main hope, therefore, is to change the rules-less by financing perpetual-minority parties than by backing political strikes and mob violence. Its stance is comparable with that of the more militant Black Power advocates in the United States-but stronger, since it represents a proportionately larger and better-disciplined constituency.

\section{Summary}

It is difficult if not impossible to summarize this jumble, crossing so many branches of social science, in any intelligent way. Certainly the performance of the Occupation in both reconstruction and development was less outstanding than I remember anticipating as an inexperienced serviceman in the relative backwaters of Northern 
Kyushu during the Occupation's initial era of good feeling. There seemed at that time no difficulty in convincing the Japanese of almost anything we wished-even those Japanese affected adversely. This euphoria, of course, did not last. It could hardly have lasted even with an occupation force of philosopher-kings and plaster saints, which ours was not.

On the other hand, looking backward, the record of the Occupation was better than I now think I had any right to expect in 1945-46, considering its brevity, its overstay of its welcome, and the resulting temptation to ride roughshod over Japanese public opinion. One thing is certain: I know of no military occupation which did much better with similar obstacles in an equally large and alien environment.

\section{Notes}

1. Two summaries of detailed statistical estimates may be found in Harry Emerson Wildes, Typhoon in Tokyo (New York: Macmillan, 1954), p. 2, and Edwin O. Reischauer, The United States and Japan (Revised edition; New York: Viking Press, 1957), pp. 207-210.

2. Wildes, op. cit., p. 309 .

3. This is Ambassador Reischauer's judgment. (Reischauer, op. cit., p. 232).

4. Two well-known statements dating from 1945 are: "The plight of Japan is the direct outcome of its own behavior and the Allies will not undertake the burden of repairing the damage" and "The only responsibility on our part for the Japanese standard of living is the purely negative one prohibiting us from requiring for the Occupation Forces goods or services to an extent which would cause starvation, widespread disease, and acute physical distress." The first statement is by the Joint Chiefs of Staff (with presidential approval); the second is by the State, War, and Navy Coordinating Committee. Wildes, op. cit., p. $208 \mathrm{f}$.

5. G. C. Allen, Japan's Economic Recovery (New York: Oxford University Press, 1958), Table 23, p. 203.

6 . Between 1946 and 1952 , the proportion of land farmed by tenants was reduced from 46 to 8 per cent of the total cultivated area. Ibid., p. 57, citing a Japanese work by Yasuo Kondo, p. 139.

On the confiscatory character of the reform, A. J. Grad estimates that the statutory price of a tan of good rice land paid a landlord in 1948 would have bought 13 packs of cigarettes or 0.24 tons of coal, whereas its pre-war value was over 3000 packs of cigarettes or 31 tons of coal. Cited in Ronald Dore, Land Reform in Japan (New York: Oxford University, Press, 1959), p. 139.

At the same time, the reform was not a purely American idea foisted upon unwilling Japanese: It rested heavily on the thinking of pre-war Japanese agricultural radicals. Ibid., p. $147 \mathrm{f}$.

7. The quoted passages, from Wolf Ladejinsky and Ronald Dore, are in Dore, op. cit., p. 148 .

8. This arbitrary definition, which corresponds well with professional usage, is by Phillip Cagan, "The Monetary Dynamics of Hyperinflation," in Milton Friedman (ed.) Studies in the Quantity Theory of Money (Chicago: University of Chicago Press, 1956), p. 25.

9. Institute of Economic Research, Hitotsubashi University, Annotated Economic Statistics of Japan for Postwar Years (Tokyo: Hitotsubashi University, 1960) Tables IX-2, IX-3, pp. 120, 122. The figures probably exaggerate the post-war inflation, since 1945 was a year of controled prices and extreme scarcities at those prices. High-quality continuous series for retail or consumer's prices outside Tokyo are hard to find for pre-war years. 
10. I owe to Kei Shibata, exchange Professor at Carnegie-Mellon University in 1967-68, fuller realization of Japanese war industry's vested interest in postwar inflation.

11. Exceptions to the "no-punishment" generalization were firms like the South Manchuria Railway in China and the Oriental Development Company in Korea whose assets were confiscated when the Japanese lost their overseas empire.

12. Kozo Yamamura, Economic Policy in Postwar Japan (Berkeley: University of California Press, 1967). Professor Kogiku and the present writer have made a similar point in another field (taxation), where the Japanese have seemed to have sacrificed equity to capital formation, despite the opposite preferences of foreign critics. M. Bronfenbrenner and K. C. Kogiku, "Aftermath of the Shoup Tax Reforms-II," National Tax Journal (December, 1957).

13. Perlman, Theory of the Labor Movement (New York: Macmillan, 1928) pp. $3-10$. 
$-$ 


\title{
The American Occupation of Japan: Social Retrospect
}

\author{
Edward Norbeck
}

The title "Social Retrospect" covers an immense field. Some months ago I consulted a half-dozen colleagues in anthropology who specialize in Japanese culture, asking what subjects they would most like to have discussed. The responses were essentially uniform expressions of opinion that agree with my own. All regarded the task at hand as formidable for a brief paper. None expressed any explicit interest in the question of whether or not the Occupation had been in competent human hands. All rated as the most important subject the social changes relating to individual freedom embodied in the postwar Civil Code. Three additional subjects were recommended for discussion, and I have rated these in descending order of importance according to the emphases given them by my colleagues. The subjects are then:

Primary subject:

Social reforms embodied in the postwar Civil Code

Lesser issues

Educational reforms

Religious reforms

Land reform

I shall first discuss the lesser issues.

Educational reforms: Among the issues we have selected for discussion, the reforms in education instituted by the Occupation are presently the subject of the greatest contention in Japan, and many persons have branded the reforms as failures. The directive of the Occupation forbidding the teaching of morality and Japanese history and geography in the public schools seems absurd. The intent of the directive was, of course, to eliminate the threat of future military aggression by prohibiting the teaching of nationalism in the schools. The most contentious issue was the teaching of "morality," which was resumed in 1958. The intent of SCAP's directive has, however, been carried out. After working my way through one of the series of 
morality books in use today, I would describe their contents as harmless, inspirational pap containing far less nationalism than The Reader's Digest but often resembling that magazine in general tone.

Much argument wages in Japan today about the proper roles of the Ministry of Education, the legality and the value of teaching morality, the desirability of co-education, and the suitability of the division of the schools after the American model into a sequence of 6-3-3-4 years. The loudest voice of complaint comes from the teachers' union, Nikkyoso, in opposition to the Ministry of Education.

Let us note that with the possible exception of resuming, in altered form, the teaching of prohibited subjects, no real reversion to a former state has taken place: the Ministry of Education continues to have a good deal of authority. Let us note also that the vocalizations of Nikkyoso were made legally possible and morally acceptable by the educational reforms. Dissension over public education is obviously not remarkable in democratic nations.

I interpret the resumption of instruction in morality as a response to strong national expressions of alarm over a putative decline in moral standards. This apparent erosion of morality, in turn, seems to me in large part simply a change in conceptions of morality that has accompanied social changes of other kinds and tends to be viewed by senior citizens as moral defection rather than change. Japan today is not a land of moral chaos or anarchy. The religions of Japan have not traditionally taught morality explicitly or systematically; the schools since Tokugawa times have done so-and for a time nationalism was incorporated in those teachings.

I would guess that part of the furor over education is an expression of concern over lack of facilities. Japan's lifeline in international competition in trade and industry depends more and more upon advanced education. Despite phenomenal growth of institutions of higher education during the past decade or so, the facilities cannot meet demands.

Religious reforms: For the past four years I have conducted research on the subject of Japanese religions. I shall discuss it here only very briefly. Reforms in religion brought about by the Occupation consisted principally of a provision in the new constitution establishing religious freedom (thus ending governmental control of religion), the end of national support of Shrine Shinto, and the associated prohibition of so-called emperor worship in the nation's schools. Otherwise, 
the Occupation treated religion in Japan in a gingerly way, leaving most matters for settlement by the Japanese themselves.

Since the end of the Occupation there have been no atavisms. Some pressure is being exerted to gain financial assistance from the government for the maintenance of certain shrines, and these efforts will eventually succeed, I think, because the structures in question hold informal statuses as national museums. Some national concern is felt over the growth and activities of postwar religious sects, notably Soka Gakkai, and the possibility of their influencing national affairs in an undemocratic direction. The most noteworthy development, however, is the growth of secularism. Most of the nation shows little interest in religion, and this may be regarded as entirely congruent with legal provisions giving religious freedom.

Land reform: There is probably agreement that the land reform brought substantial and very quick results in improved agricultural economics, but the land reform has often been branded a failure or only a partial success, for two principal reasons. One is the agricultural crisis of the past decade associated with the accelerated industrialization and urbanization of the nation, which has drawn farm labor to more lucrative employment in the cities and made unprofitable the operation of the small farm holdings of which ownership is permitted under the regulations of the land reform. The second major source of complaint is of unfair treatment of former landlords. Occupation authorities appear to have assumed, erroneously, that landlords as a class were unscrupulous exploiters of helpless tenants. Compensations given to landlords were so small that they might better have been called confiscation fees.

A decision of the Supreme Court in 1953, however, upheld the provisions of the land reform as legal. Neither SCAP nor the Japanese government could have foreseen in 1946 or 1948 the trend of national economic development that would make the regulations of the land reform unsuitable by the 1960's. Although some action or thought of action toward substantial changes in agricultural policies is now taking place, revisions of the land reform so far have not been great. The outstanding action is the legislation enacted in 1965 to remedy inequities of compensation to landlords ( $¥ 145,600$ million to be paid to 1,670,000 landlords in the following ten years). Even this legislation preserves the spirit of the land reform: the sums being paid to landlords are called solatiums rather than compensation. 
The Civil Code: Provisions of the postwar Civil Code may be described briefly as extending increased individual freedom to the citizenry in general. Its most remarkable features were provisions making women the legal equals of men and the abolishment of primogeniture. The implied effect of these reforms with respect to the form and functions of the Japanese family is profound, particularly the loss of legal authority of male family heads that the new code entailed.

After the end of the Occupation, some attempts were made to revise the Code, but these were outstanding failures. The provisions of the Code remain intact today, and there is little likelihood that any reversions to a former state will ever occur. To be sure, primogeniture still generally prevails among farm families, but the position of the eldest son as the heir and the caretaker of his aged parents is now generally regarded as one of obligation rather than privilege. Younger brothers and sisters are provided for, and since they are not tied to small farms and the care of aged parents, they are generally regarded as being in a position better favored than eldest brothers for economic success and general well-being. In any case, division of the small farms into still smaller holdings is economically unsound.

Women are certainly not the equals of men today, but much evidence exists that women can and do assert themselves and that their status has risen greatly. Evidence is in the forms of voting records of women, the activities of the nationally organized Women's League (Shufuren), divorce suits initiated by women, the rising number of female college students, and much else-including the rising number of women who desert families. Most striking-and most revealing in explanation of their social ascent-is the great importance of women in the national labor force.

Since these various social reforms instituted by the Occupation have by and large been retained, one might well assume that the Occupation was successful. But let me approach the issue of success or failure by asking two questions:

1. To what extent was the Occupation truly innovative in its social reforms?

2. Did the Occupation help or hinder Japan, and how did it do so? 
In response to the first question regarding innovations, if we examine the history of social developments in Japan since the beginning of the Meiji era, several related trends of change that bear on the issue are evident. These I shall state in only skeletal form, without pinpointing them in time or discussing plateaus and apparent halts and recessions:

1. A general decline in the functional importance of kinship and other personalized human relationships, of which the most important aspect is a great change in the nature of the Japanese family.

2. Increasing social recognition of individual talent (as opposed to status by ascription) accompanied by what the Japanese anthropologist Chie Nakane has called a growth of "I-feelings" as opposed to "we-feelings."

3. A trend toward increasing occupational mobility and associated social mobility that have been both concomitants of and requisites for economic success as an industrial nation.

4. The increasing incorporation of women into the national economy as wage earners, accompanied by an actual, if not a legal or acknowledged, rise in their social status.

5. A growing secularization of life that is attributable in part to the growth of scientific knowledge in pure and applied forms and the failure of the nation's religions to adjust to changed conditions of life.

These changes did not progress uniformly, and they may be described as coming about as insensible shifts rather than abrupt changes of direction. The social changes were not planned, and during the 1930's and the duration of World War II they were heavily masked by the demands of a totalitarian government operating with an ideology that had already become obsolete. Economists speak of Japan as having a dual economy. The circumstances implied by this term also exist in the social and religious realms, making trends of change difficult to see. At best the nation - and certainly the governmental authorities before and during the war-were only partly conscious of the social changes that had already occurred. These I shall label as being unplanned concomitants of economic changes.

Despite great ineptness on the part of the Occupation, in both 
fundamental philosophy and in qualifications of its personnel, I would describe the social reforms of the Occupation as being generally successful. This success may, I think, be attributed principally to two favorable sets of circumstances.

One is that the major social reforms of the Occupation were congruent with essentially unplanned trends of change in Japan that were partially masked from observation even by the Japanese themselves. My remarks here are least applicable to the land reform, but even land reforms are not remarkable in the history of Japan. A small reform was conducted during World War II, and various others had preceded it. The reforms were doubtless more drastic than changes arising from within Japan might have been - and it seems reasonable to think that for this reason they helped speed Japan on its way toward economic recovery.

My statement concerning congruence intends to imply that a social similarity $\rightarrow$ a similarity but not precise identity-exists in social conditions of the United States and Japan. This similarity I shall describe briefly as a function of congruence, in both nations, between economic and social organization. I shall add that similarity does not end at this point. As many persons have noted, an analogue of the Protestant ethic is thoroughly established in Japan. The force of the Japanese drive to achieve could not have been measured, or its effects foreseen, by the American personnel of the Occupation (or, apparently, by the Japanese themselves). The social and economic changes occurring in Japan since 1952 are probably greater than the expectations of the most hopeful of the authorities of the Occupation.

The second set of favorable conditions relates to traits and values of the personnel of the Occupation and of the Japanese citizenry. Despite its logically impossible task of imposing democracy, the Occupation was favored for success fortuitously by the attitudes and values of its personnel. I refer here to the overall manner, tone, and objectives of the Occupation as expressed by the behavior of most of its personnel. To be sure, the Occupation forces included the normal complement of exploiters, drunks, incompetents, and ne'er-do-wells, but such people were not the mode. The Japanese soon saw that the goals of the Occupation were not exploitative but were essentially missionizing - to help, and to help set the Japanese nation onto a course of life that the Americans deemed the only desirable one. 
Much of the effectiveness of the Occupation seems to have come from personal contacts between Americans and Japanese as individuals, contacts that led each side to conclude that the other did not fit the unflattering stereotype expected.

To sum up, I would say that the success of the Occupation in its social reforms is attributable much less to witting planning than it is to good intentions and a particularly favorable compatibility of values, consciously and unconsciously held, between the Americans and the Japanese.

Perhaps a suitable final measure of the results of the Occupation is an examination of the relationship that exists today between Japan and the United States. The following quotation is taken from the report of the Japanese-American Assembly, a group of seventy-six distinguished Japanese and American citizens representing various occupations and including a number of well-known American university professors. The Assembly, conducted under the auspices of The Japan Council for International Understanding and the American Assembly of Columbia University, met in Shimoda, Japan, on September 14-17, 1967. The Final Report of the Assembly opens with these words.

"The Japanese-American relationship is one of the remarkable achievements of the postwar period. It is based upon a wide congruence of interests and has in general functioned well in the interest of both countries." 


\section{Comment}

John M. Maki

The three papers by Professors Bronfenbrenner, Norbeck and Ward deal with an implicit theme of considerable significance: the Occupation and social change in Japan. All three of them center on the phenomenon of institutional change in the economic, social and political spheres of Japanese society, but the extent of institutional change was of such a degree that it necessarily brought with it a considerable shift in the society's value system.

Bronfenbrenner has discussed three economic successes and three failures resulting from occupation policies. Land reform, a success, and Zaibatsu reform and the union movement, both of which he treats as failures, all involved institutional changes of considerable magnitude. Even though both Zaibatsu reform and the union movement can be classed as failures because they fell short of what might have been, the fact remains that both big business and labor, as institutions, are far different today from what they were in 1945. Norbeck has described significant changes in Japan's educational, religious and social institutions. Of special importance are changes in the family system, particularly as they affect the position of women. Ward has emphasized institutional changes in politics of far-reaching significance: the establishment and effective operation of representative and responsible government, free elections, and the acceptance of the doctrine of popular sovereignty.

What we observe is a battery of changes affecting institutions ranging from the family to the national government. These changes have not been confined merely to structure. They have been accompanied with an even more striking alteration in the Japanese system of values. I am fully aware of the difficulties involved both in determining the content of a system of values in any society and the nature and extent of change in such a system. Although it may appear simplistic, I believe it is not misleading to state that a society's system of values is that set of norms, attitudes and beliefs generally shared by members of the society and used to form judgments of the "goodness" or "badness" of individual and social actions, situations and relationships.

Both the nature of a system of values in general and the changes that have come over Japan's can be illustrated by a few examples 
drawn from the institutional changes dealt with in the three papers under discussion. Prior to the Occupation labor unions were held to be so "bad" that their very existence was illegal; today unions as institutions are accepted as "good," even though some of their actions may be deplored by many Japanese. Prior to 1945 the patriarchal family and the inferiority of women were "good"; today they are rejected. Prior to 1945 an authoritarian government based on imperial sovereignty was "good"; today the politically "good" is a democratic government based on popular sovereignty.

The impressive degree of institutional change with the accompanying shifts in the value system raises the obvious question: Why? I do not propose to attempt an answer. I simply wish to mention a few matters that may conceivably lead toward an answer. It seems to me that a useful initial step would be to try to describe somewhat more precisely the nature of the process of change initiated under the Occupation.

In the first place, I would like to point out that it seems to me that there are three very broad types of social change under which Japan's cannot be classed. First, it is apparent that what Japan has been going through since 1945 is not the type of social change that was involved in its modernization at the end of the 19th century. The differences are so obvious that they require no comment. Second, it is not the kind of change that is involved in modernization as a contemporary phenomenon of new nations. What is happening to them today is roughly equivalent to what Japan experienced between about 1870 and 1900. Finally, it is perfectly clear that what Japan has gone through since 1945 is not exclusively the process of what might be termed self-generated change which normally takes place within any society and that arises from the very nature of society and its ongoing processes. Although there is clearly a strong element of self-generated change in Japan, as Norbeck and Ward both emphasize, it is crucial to an understanding of post-1945 Japanese social change to start from the central theme of this discussion, namely, the Occupation.

It has occurred to me that perhaps any attempt to analyze Japan's recent social change might best start from the view that it is unique and, consequently, must be studied in itself outside the possible terms of reference I have indicated. What makes the Japanese situation unique, I think, are three key features of the society at the end 
of the Second World War. The first was the disruptive effect of the war itself on the entire fabric of Japanese society, disruption being both a manifestation of change and an impelling force toward even more change; the second, the fact, set forth by both Norbeck and Ward, that Japan's society was one that two generations earlier had passed through the initial stages of the broad process of modernization and was therefore possessed of the panoply of institutions characteristic of a modern society; and the third, the Occupation itself which created a peculiar state of inter-action between a foreign society as represented by the almost completely American Occupation and Japan.

As I have considered the problem of change in Japan since 1945, I have come increasingly to feel that perhaps the most fruitful avenue for an approach to an analysis of the causes of Japanese social change may possibly lie in a sophisticated examination of the broad problem of inter-cultural contact between Japan and the United States. It is obvious beyond challenge that although the initial contact was in the form of a military occupation, what occurred rapidly was a societywide impact on Japan. What I mean by a sophisticated examination is basically an attempt to reach a fairly clear and accurate reading of the essentials of what has been referred to as "the national style" of both the United States and Japan. I think that as the three papers so ably demonstrate we already have what amounts to a fairly good working concept of the Japanese national style as of 1945 and since. The reason for this happy state of affairs is simply that what was happening to Japan at that time and has happened since has been sovisible and so spectacular that a considerable amount of effort has already been expended on the Japanese side of the problem.

As a result we have a fairly good idea of why Japan was ready in 1945 to embark on a course of drastic social change. But we do not know why the United States was "ready" to come up with a policy that would fit so elegantly into the requirements of the Japanese situation. We know, for example, what the content of American policy for the Occupation of Japan was, but no one, to the best of my knowledge, has really come to grips with the fundamental issue of why it was that American society operating through individuals in key positions in the United States government was able to create its far-reaching policy calling for fundamental changes in many areas of Japanese society. Perhaps no real problem exists; perhaps it is enough 
to say that "American idealism" in matters economic, political and social was the source of both the policy and the acts that implemented it. But if my statement of the problem approaches validity then it seems to me that some aspects of the American side should be subjected to as searching an examination as has been applied to the Japanese side.

Even if we do end with a more sophisticated view of the two societies as of 1945 than I believe we currently possess, we would still be at only an initial stage in our investigation of what appears to me as an even more fundamental and fascinating question: Why was it that two such obviously dissimilar societies were able to interact as effectively as they did in the complex process of the introduction and maintenance of rapid and extensive social change in Japan? I have no idea as to the possible nature of an answer to this question, but I stoutly maintain that it is a valid one which has not yet been seriously addressed.

As I have indicated, I think that the Japanese themselves and a number of foreign students of Japanese society have already soundly approached the study of the Japanese half of the problem. I am less sanguine about the development of a parallel study of the American role in the process or even of an awareness of the importance of a more careful and accurate delineation of the nature of the American partner in the interacting relationship.

I would like to see at least as many Japanese social scientists as seriously interested in the problem of American social change since 1945 as there have been American social scientists working on the Japanese phenomena of social change. I think that there is a very simple reason why Americans have not paid more attention to the problem of the nature of the American partner in the JapaneseAmerican relationship: the American preoccupation with self-proclaimed failures of American policy in Asia coupled with what seems to be an almost pathological inclination to ignore reasonable successes such as the American role in the generation of a broad series of changes in Japanese institutions and the associated system of values. 


\section{Comment}

\section{Harry Emerson Wildes}

This is not an age of optimism, but it is discouraging to hear that given time, indoctrination and a period of successful administration, people will adapt themselves to almost any political circumstance. The thesis may be historically correct; after all, few uprisings break out against absolutism, benevolent despotism, fascism, bureaucracy or militarism while people are prosperous. It is, however, comforting that, as Professor Ward reminds us, the political devils are, in the long run, helpless against liberalizing and progressive social forces.

Such forces, as all agree, were operating within prewar Japan. Unhappily, SCAP, in all his wisdom, failed to point out that foundations existed for what we like to think of as the Occupation's reforms. It was unfortunate, also, that Occupation leaders either ignored or sadly misread the social and economic situation.

The causes for the misconception, as Professors Bronfenbrenner and Norbeck note, were manifold. High among them was the assumption by military men that, despite an insufficient training, they were more efficient social scientists than were their professorial underlings. The Occupation included aides whose quality, taken as a whole, at least equaled that of the faculties in any university, but the military men often did not consult and usually did not heed professional advice.

Not all the advice was flawless. Some of the supposed experts, perhaps those whom Professor Norbeck terms inept, or whom Professor Ward describes as moved by evangelical zeal, looked upon Japan as a laboratory for Utopian experiment. Few of the more radical suggestions came before staff meetings but, of those that did, I fail to recall one instance in which any psychological, historical, political or sociological factor was even mentioned.

The military section chiefs, the men whom, as rumor ran, the Supreme Commander had already chosen as his Presidential Cabinet, apparently lacked knowledge of, and respect for, the social sciences.

The Occupation's official history, so egocentric that its writers, on the purely military side, worked under orders to mention General MacArthur's name on every single page, minimized all history which did not prove Japan's steady lapse into autocracy, brutality, aggression and evil propaganda. 
No one could disabuse the overlords of certain firmly-held obsessions. Chief among them were the myth of Emperor worship, the idea that Japan was bent on Asian and Pacific, if not world, mastery, and the conviction that the rightists, though thoroughly discredited by defeat, were on the verge of regaining supreme control. Every Japanese social institution, it was believed, was primarily dedicated to restoring militarism.

SCAP suffered from lack of unbiased information. Few of the policy makers spoke Japanese, fewer still possessed a reading knowledge of the language, and virtually none circulated freely among the native population. Except for one GHQ section which hired certain officers of the former Japanese General Staff as an anti-Communist intelligence group, contact with what the Occupation termed "indigenous personnel" was strictly limited when it was not expressly forbidden.

During the first year or two of the Occupation, the period when SCAP directives poured out in a paper torrent, the Occupation relied for current news about Japan on three sources, all of them heavily suspect. A daily digest of translations from a cautious, if not heavily censored, vernacular press circulated in one of the most powerful GHQ sections. Some dependence was laid upon native informers, rewarded for their service by various perquisites. As sweeping purges, real or supposedly imminent, barred most experienced Japanese from SCAP offices, these informers were largely leftists, most of them amateurs who, prior to surrender, had been unimportant; others were smooth operators with adjustable principles. Taken together, these informers produced a flood of slanted "news," crammed with misinformation, distortions, doubletalk and self-advancement. They also retailed slander which, because of its "revelations" and its spiciness, was readily accepted.

Most Occupationaires were not, however, blessed with such sources; they gained their information from the Army paper, Stars and Stripes, then masterminded by far-leftist propagandists. It was they who startled Japan by arranging a rousing welcome, on MacArthur's sacred sixth floor of the Dai Ichi Building, for the return from exile of Sanzo Nosaka. Some misguided Japanese interpreted the reception as proof that the American Occupation was in fact proCommunist.

That, despite drawbacks, including, as Professor Norbeck notes, 
American ineptness, the Occupation achieved such successes as all three papers describe, can be credited to Japanese-American co-operation. Advances toward individualism, liberty, equality, unionism, press freedom and tolerance were furthered, certainly, by Occupation pressure. An annoying query rises, however. Since prewar progress, however slight, had picked up considerable momentum in Japan and since these desirable reforms were causing ferment elsewhere in the world, how much change would have occurred in Japan had the Occupation never existed?

Other problems present themselves. Occupationaires who certainly were not drunkards, exploiters, or ne'er-do-wells, though some of us may indeed have been incompetent, worked zealously to remake Japan. Did they invariably know precisely what their plans implied? All too often SCAP directives used words such as democracy which did not always convey the same overtones to Japanese as to Americans. Did either Japanese or Americans understand in full detail just what consequences to expect?

SCAP takes bows if the reforms succeeded, but who is to blame if they fell short? Apparently there are flaws in Japan's educational system and also in the economic program which Professor Bronfenbrenner so well described; did the Occupation blunder, did Japan sabotage the plans or are American methods inapplicable to Orientals? Then, too, can we use these blueprints, some future day, in Vietnam?

For that matter, have Americans satisfactorily solved their own problems? Are our farmers happy, our women pleased with their position, are labor and management in full accord and our race relations joyous? 